\title{
Adjacency Pairs in Drama Script “Teen Angel” by D.M Larson
}

\author{
Ita Permatasari, Listiyanti \\ Sebelas Maret University
}

\begin{abstract}
Menjadi salah satu bagian penting dalam era globalisasi, pemahaman akan bahasa Inggris sangatlah diperlukan untuk menaklukkan beberapa aspek kehidupan yang dipengaruhi oleh bahasa itu sendiri misalnya dalam bidang ekonomi,sosial dan juga politik. Sebagai jembatan dari dua orang yang berkomunikasi, percakapan menjadi salaha satu bagian bahasa yang dianalisa oleh beberapa praktisi bahasa. Dalam penelitian ini, peneliti melakukan Conversation Analysis atau CA. Data didapatkan drama sebuah drama berjudul "Teen Angel" karya D.M Larson. Dua pertanyaan yang ingin dijawab oleh peneliti adalah (1) Apa jenis-jenis adjacency pairs yang muncul di dalam drama? Hasil penelitian menunjukan bahwa terdapat 245 turns, dimana 103 data (turn-taking) diklasifikasikan ke dalam 13 tipe adjacency pairs, dan terdapat 5 presequencedan 2 insertion sequences.
\end{abstract}

Keywords: Conversation analysis, turn-taking, adjacency pairs, pre-sequence, insertion sequence

\section{INTRODUCTION}

Language has showed its significant role in many layers of human life. The existence of language, clearly, helps people to face some miscellaneous things related to economic, politic, social and communication aspect. Therefore, comprehending language skill is needed for those who want to fuse with those aspects. Language takes a role as the bridge of conversation which may connect two people in daily life. Levinson $(1983 ; 284)$ stated that "conversation is clearly the prototypical kind of language usage, the form in which we are all exposed to language-the matrix for language acquisition". Moreover as stated by Herritage (2001:274), "conversations are social creations in which they are produced one step at a time as people carry out certain joint activities". It can be said that conversation is the time when two or more people trying to build social interaction by transferring information to each other.

When people are having a conversation, they actually held a joint activity. In every joint activity, engages two components include participants and goals (public goal and private goal). Based on Herritage (2001: 2744), participants refer to the people who actually taking part in a conversation, he or she takes particular role. Also, every joint activity has public goals such as gossiping, negotiating or persuading.

One of the basics mechanisms of conversation is turn-taking. Turn taking defines as a process involving the speaker and the listener who take and change the roles in order to transfer information to each other (Coulthard, 1985: 59). Also, conversation takes adjacency pairs as its basic structural units in conversation in which used for opening and closing conversations, (Coulthard, 1985; 70). There is a relationship between two utterances in discourse which two-part. Kristina (2014: 24) states that adjacency pair is not only linguistically related but also socially related because it accomplishes social actions. Adjacency pairs can be defined as sequences of two related utterances which are given by two different speakers in which his second utterance is always a response to the first.

There are some features of adjacency pairs proposed by Levinson $(1983 ; 303)$ that adjacency pair is sequence of two utterance in which: (1) adjacent or that is, one after the other, (2) produced by different speakers, (3) ordered as a first speaker (FPPs, or Fs for short) and a second speaker (SPPs, or Ss for short), (4) Pair-typed in which there are exchanges such as greeting-greeting, question-answer and the like.

In this study, the researcher categorized the conversations inside drama "Teen Angel" into several types of adjacency pairs proposed by Levinson (1983; 303), Coulthard (1985; 69) and Schegloff $(2007 ; 13)$. There are greeting-greeting (1), summons-answer (2), apology-minimization (3), question-answer (4), request-acceptance/refusal (5), offer-acceptance/refusal (6) , blame-admission/denial (7), invitationacceptance/refusal (8), assessment- agreement/disagreement (9), command-compliance/ incompliance (10), 
suggestion-acceptance/refusal (11), assertion- agreement/disagreement (12) and announcement-acknowledge (13).

Another term that becomes the focus of this study related to adjacency pairs are pre-sequence and insertion sequence. Pre-sequence is defined as the sequence which occurs before the first pair part (Levinson, 1983: 345) while insertion sequence is that where adjacency pair comes between the first pair and the second pair part of another adjacency pair (Paltridge, 2006:118).

Being academic practitioner, especially English teachers, comprehending types of adjacency pairs should be done considering that they will teach speaking skill to the students. By knowing the types of adjacency pairs, teachers are expected to give clear understanding of such kinds of appropriate response when the students involve in real conversation. Furthermore, the following terms such as pre-sequence and insertion sequence are important to introduce, as, sometimes in a conversation, the speaker will not come directly to the purpose of utterance. Also the types of adjacency pairs can be brought into writing class as the students can be exposed to response acuratelly certain utterance.

The researcher used the drama script "Teen Angel" by D. M. Larson as the object of the study. The research is aimed to know the types of adjacency pairs formed in the conversations between characters involved in this drama. There are 7 characters involved in this drama. Second, it is aimed to know how the types of adjacency pairs can be used in the speaking and listening class.

The drama tells about a girl namely Peggy who went to afterlife after she got car accident and came back to the real life, having a mission to get wings, as a permission of an angel called Gabrielle in order for her to go to heaven. In her disguise, she pretended as Pamela and met Kate, part time employee in a café. Kate, who became her friend, actually loved, Rick, her ex-boyfriend. During the mission, she also met dark angel called David, who turned to be the one who caused the car accident in which Peggy died on it. Then, Peggy decided to help Kate to get closer to Rick. Finally, as Peggy and David broke the rule for not remembering any memory, they were not given wings and trapped in the real world.

Before talking further about Conversation Analysis, it should be considered to distinguish it with Discourse Analysis (DA). DA used both the methodology and the kinds of theoretical principles and primitive concepts typical of linguistics. It is essentially a series o f attempts to extend the techniques o successful in linguistics, beyond the unit of the sentence. The procedures employed (often implicitly) are essentially the following: (a) the isolation of a set of basic categories or units of discourse, (b) the formulation of a set of concatenation rules stated over those categories (Levinson, 1983; 286).

In the other line, Conversation analysis (or CA), is a rigorously empirical approach which avoids premature theory construction in which the methods are essentially inductive; search is made for recurring patterns across many records of naturally occurring conversation (Levinson, 1983; 287).

\subsection{Turn Taking}

One of the basic facts of conversation is that the roles of speaker and listener change and this phenomenon occurs with little overlapping speech and few silences. A second feature of conversation is that speaker change recurs, and this presents problems for the participants (Coulthard, 1985; 59). There is description of turn taking stated by Levinson $(1983 ; 296)$ as: one participant, A, talks, stops; another, B, starts, talks) stops; and so we obtain an A-B-A-B-A-B distribution of talk across two participants.

\subsection{Adjacency Pairs}

Adjacency pairs seem to be a fundamental unit of conversational organization which is deeply inter-related with the turn-taking system as techniques for selecting a next speaker (Levinson, 1983; 303). A conversation is a string of at least two turns. Some turns are more closely related than others and he isolates a class of sequences of turns called adjacency pairs.

Adjacency pairs have the following features: they are two utterances long(1), the utterances are produced successively by different speakers (2), the utterances are ordered - the first must belong to the class of first pair parts, the second to the class of second pair parts (3), the utterances are related, not any second pair can follow any first pair part, but only an appropriate one (4), the first pair part often selects next speaker and always selects next action - it thus sets up a transition relevance and expectation which the next speaker fulfils, in other words the first part of a pair predicts the occurrence of the second (5) (Sacks, 1967 in Coulthard,1985; 69).

\subsection{Preference Organization}

In the vast majority of sequence types, there are not only alternative responses which a first pair part makes relevant and a recipient of a first pair part may employ; there are alternative types of response, and these embody different alignments toward the project undertaken in the first pair part (Scegloff,2007;58), Added by Pomerantz (1984:63-64), the key issues in the organization around "preference" and "dispreferrence" concern the alignment in which a second action stands to a first, and 
the alignment which recipients take up toward a first pair part by the second pair part which implements their response.

\subsection{Pre-sequence and insertion sequence}

Sometimes, in a conversation, pre-sequence (pre-invitations, pre-requests and pre arrangements) occurs. These are psychologically motivated structures to avoid loss of face for one or both participants resulting from a dispreferred second having to be performed. Besides, there is an embedded pair called as insertion sequences. The structures described so far have been linear, one pair followed by another; there are also cases of embedding, of one pair occurring inside another (Coulthard, $1985 ; 71)$.

\section{RESEARCH METHOD}

Conversation Analysis (CA) is the approach of this study. Kristina (2014; 23) defined Conversation Analysis as a study in which exploring the patterns of social life represented in a conversation (dialogue). The data source of this study was taken from the drama "Teen Angel" by D. M. Larson. The data used are the conversation between the characters in the drama in the forms of word, phrase, clause, sentence, utterance and expression. The primary instrument of this study is the researcher itself whom selected, collected and analyzed the data. The procedure of the study can be seen as follows:

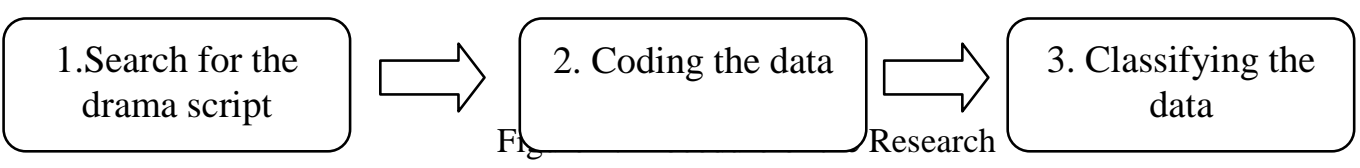

In analyzing the data, the researcher came to the several steps. First, the drama script was coded and classify into several types of adjacency pairs. Next, the data were analyzed by describing each utterance and counting the data findings. Last, the researcher drew a conclusion based on the whole discussion.

\section{RESULTS AND ANALYSIS}

Based on the observation, the researcher found some turn-taking in the drama script "Teen Angel". There are 245 turn-taking concluding greeting, summons, apology, questions, requests, offer, blame, invitation, assessment, command, suggestion, assertion and announcement. The data, then, were classified into 13 types of adjacency pairs. The researcher provides one example of each type. The result can be seen as follows.

\section{Adjacency Pair \\ Greeting-Greeting}

In this drama, the researcher found 5 data which are classified as greeting-greeting. Greeting is such kind of utterance occurred in the beginning of meeting or when two people meet for the first time and introduce who he/she is. The following turn-taking is the example of greeting-greeting found in the drama.

Peggy : No problem. Hi, I'm... Pamela.

Kate : I'm Kate... what did you say your name was again.

Peggy : Uh... Paula.

Kate : Nice to meet you, Paula. I better get back to work.

This utterance occurs when Peggy meets Kate for the first time and she greets and introduces herself by saying "Hi" and mentions her name "I am Pamela" (turn 1). The second pair, who is Kate, responses by mentioning her name and closes it with saying "Nice to meet you" (turn 4).

Summon-Answer

Summons is a kind of adjacency pairs when the first pair summons the second pair. The researcher found 3 data categorized as this type of adjacency pairs. In the example of summons below we can see that Kate summoned Peggy by saying "Hey"(turn 1) in order to make Peggy recognized that she was called. Next, Katy added "How does everything look?" (Turn 2) and Peggy answered the summons and the questions by saying wonderful.

Kate: Hey, Peggy. How does everything look?

Peggy: Wonderful. You look great too.

\section{Apology-Minimization}


Apology is one of the types of adjacency pairs which occur when someone makes a mistake and he/ she wants to make an excuse. The word "sorry" is usually used in making apology. There are 6 data of this type.

Kate : I'm sorry. I didn't mean to upset you.

Rick : No, it's fine, Kate. Thank you.

From the conversation above, it is clearly seen that Kate did an apology by saying "I am sorry" (turn 1). As the response of the apology, Rick came up with the minimization in the form of "No, its fine" (turn 2), indicates that Rick accept the apology.

\section{Question- Answer}

Question- answers type is the most data which occurs in this drama script. There are 55 data found which are considered as questions-answers. All of the data offer preference as the second pair provided answer for the first pair. The example of this type can be seen as follows:

Peggy : What happens if I don't earn my wings?

Gabriella : You will earn them. I know you will.

This utterance involved the main character, Peggy, and the angel, Gabrielle when they met for the first time. The first pair, Peggy, gave a question "What happens if I don't earn my wings?" (Turn 1). The second pair, Gabrielle, provided the answer by saying "You will earn them. I know you will." (Turn 2).

\section{Request- Acceptancel Refusal}

In this drama script, the researcher found only 1 data categorized as request type. This kind of type refers to the utterance in which the speaker, first pair, asks the second pair to do something.

Kate : Please, can you stop it?

Heather : What are you going to do? Get your boyfriend to stop me?

Kate : No, don't.

This utterance occurs when Heather came to the cafe where Kate was working and she messed up the table by pouring some ketchup on it. The first pair, Kate, requested Heather to stop the action by saying "Please, can you stop it?" (Turn 1) and sadly Heather refused it by implicitly saying "What are you going to do? Get your boyfriend to stop me?" While continued to mess the table.

\section{Offer-Acceptancel Refusal}

There are 6 data categorized as offer type. Related to preference organization, there are 4 data included in preferred second pair part and 2 data which in dipreferred second pair part. Offer is one kind of adjacency pairs in which the first pair part suggest to do something his or herself as a favor for somebody else or a suggestion from somebody to give something or do something for somebody else

Rick : I'll help you clean up.

Kate : No, it's okay.

This conversation occurs when Rick saw Kate in the cafe and wanted to help Kate clean up the table. The first pair, Rick, offered a favour by saying "I'll help you clean up" (turn 1). Kate came up with the dispreferred second pair part by saying "No, it's okay" (turn 2).

\section{Blame-Admission/denial}

Blame can be defined as type of adjacency pair to consider somebody to be responsible for something wrong or unfortunate that has happened. In this drama script, there are 2 data considered as blame type in which both the second pair parts in the data showed dispreferred response.

Peggy: You were the guy that crashed into Rick. I remember now.

David: No, don't remember, please. We can't or we'll be trapped here.

On this data, the first pair blames the second pair by uttering "You were the guy that crashed into Rick. I remember now". This utterance happened when Peggy realized that David is the one who caused the accidence that made Peggy died. The dispreferred second pair part denied it, implicitly, by saying "No, don't remember, please" (turn 2).

\section{Invitation-Acceptance/refusal}

There are 2 data in this drama script categorized as invitation type. Invitation type occurs when the first pair offers to come or go somewhere, especially one promising pleasure or hospitality, or the making of such an offer, or encouragement to do something. The second pair could provide acceptance as the preferred form or denial as the dispreferred form. 
David : Then let's find you a boat. Oh, I love this song.

Peggy :Me too.

David :Want to dance?

Peggy :I'd love to.

The invitation type can be seen when the first pair, who is David, asked the second pair to dance together with him "Want to dance?" The second pair, Peggy, gave acceptance by saying "I'd love to". Both of the data which considered as invitation type in this drama are categorized as preferred organization.

\section{Assessment- Agreement/disagreement}

There are 4 data considered as assessment type. All of the data are preferred second pair part. A conversation which is categorized as this type shows judgement about something based on an understanding of the situation.

Peggy :You're back? But I thought I become a lost soul. I broke the rules. I have my memories.

Gabriella :Yes, you did break the rules. And David, they're not too happy with you down below either.

The assessment type can be seen as Peggy judge herself that she broke the rules that Gabrielle had already explained, "I broke the rules. I have my memories". Gabrielle agreed with the judgment by saying "Yes, you did break the rules".

Command-Compliance/incompliance

Command is one kind of adjacency pair in which the first pair part giving an instruction or order to the second pair. The preferred form is compliance while the dispreferred form is incompliance. There are 4 data of this type, 3 preferred second pair part and 1 preferred second part.

Alice: Hurry up with the pickles, Kate.

Kate : Okay

In the conversation above, the first pair part, Alice, gave command by saying "Hurry up with the pickles, Kate". The second pair part, Kate, gave preferred form by saying "Okay".

Suggestion-Acceptance/refusal

Suggestion type occurs when the first pair part provides or gives an idea or proposal put forward for consideration. There are 4 data categorized as this type. All of the data are preferred second pair part as the second pair part gave acceptance toward the suggestion given.

David :You better get back in the dinner. I have a feeling you'll be needed.

Peggy :Oke, thanks.

This conversation involves David as the first pair part and Peggy as the second pair part. The suggestion can be seen in the first turn "You better get back in the dinner. I have a feeling you'll be needed". The preferred form which is provided by Peggy occurred in the second turn "Oke, thanks."

\section{Assertion- Agreement/disagreement}

There are 5 data categorized as assertion type. Assertion type belongs to the utterance which in the form of a strong statement that something is true. The preferred form is agreement and the dipreferred form is disagreement. 5 of the assertion type data have preferred second pair part and one data has dispreferred second pair part.

Kate : But I know he can't. He still loves Peggy.

Peggy : Peggy is dead. He needs to move on.

Kate : He loved Peggy so much. He still has all these pictures of her on his dashboard. It's like a little shine. I don't think he'll ever get over it.

Peggy : Let me help you, Kate. I'll help you get Rick.

The first pair part, Kate, showed her belief that "He", refers to Rick, stills love Peggy. The second pair part showed her disagreement "Peggy is dead. He needs to move on", yet the first pair part giving an assertion by saying "He loved Peggy so much. He still has all these pictures of her on his dashboard. It's like a little shine. I don't think he'll ever get over it.". The second pair part, one again, showed her disagreement implicitly by uttering "Let me help you, Kate. I'll help you get Rick."

\section{Announcement- Acknowledge}

There are 6 announcements in this drama script. This type of adjacency pair does not have dispreferred second pair part. It is a kind of statement that giving people information or news so that the information or news can be known publicly. 
Kate : He is Rick

Peggy : Who is Rick?

Kate : He's only the cutest guy in school.

Peggy : You like him?

Kate : Of course. Every girl does.

Peggy : So he's not your boyfriend?

Kate : No, he doesn't even know I exist. He's more Heather's type anyway. He's the right kind of people. I'm not

Peggy : From what I can tell, you're the right kind of people.

The first pair part, Kate, gave announcement by saying "He is Rick". The second pair part did not directly give the acknowledge, instead she asked for further information about Rick. The acknowledge form occurs in the turn 8 when Peggy as the second pair part said "From what I can tell, you're the right kind of people" means that she finally got enough information about Rick.

The total numbers of utterances which occurs in the drama script "Teen Angel" by M. D. Larson can be seen in the Table.1.

Table 3.1 Turn-Taking

\begin{tabular}{llllll}
\hline \multirow{2}{*}{ No } & \multirow{2}{*}{ Adjacency Pairs } & \multicolumn{2}{c}{ Turn Taking } & \multirow{2}{*}{ Amount } & Percentage \\
\cline { 3 - 5 } & & First Pairs & Second Pairs & & \\
\hline 1 & Greeting & 9 & 7 & 16 & $6.53 \%$ \\
\hline 2 & Summons & 3 & 3 & 6 & $2.44 \%$ \\
\hline 3 & Apology & 6 & 6 & 12 & $4.89 \%$ \\
\hline 4 & Questions & 61 & 59 & 2 & $48.9 \%$ \\
\hline 5 & Request & 1 & 1 & 16 & $0.81 \%$ \\
\hline 6 & Offer & 8 & 8 & 4 & $6.53 \%$ \\
\hline 7 & Blame & 2 & 2 & 8 & $3.63 \%$ \\
\hline 8 & Invitation & 4 & 4 & 9 & $3.26 \%$ \\
\hline 9 & Assessment & 5 & 4 & 8 & $3.26 \%$ \\
\hline 10 & Command & 4 & 4 & 8 & $3.26 \%$ \\
\hline 11 & Suggestion & 4 & 4 & 16 & $6.53 \%$ \\
\hline 12 & Assertion & 10 & 6 & 20 & $8.16 \%$ \\
\hline 13 & Announcement & 10 & 10 & 245 & \\
\hline & Total & & & 4 & 16 \\
\hline
\end{tabular}

Table 3.2 shows the data of 13 types of adjacency pairs in the drama script "Teen Angel" and the percentage of each type of adjacency pairs.

Table 3.2 Adjacency Pairs

\begin{tabular}{lllll} 
No & First Pair Part & \multicolumn{1}{c}{ Second Pair Part } & Amount & Percentage \\
\hline 1 & Greeting & Greeting & 5 & $4.85 \%$ \\
\hline 2 & Summons & Answer & 3 & $2.91 \%$ \\
\hline 3 & Apology & Minimization & 6 & $5.82 \%$ \\
\hline 4 & Questions & Answer & 55 & $53.39 \%$ \\
\hline 5 & Request & Acceptance/refusal & 1 & $0.97 \%$ \\
\hline 6 & Offer & Acceptance/refusal & 6 & $5.82 \%$ \\
\hline 7 & Blame & Admission/denial & 2 & $1.94 \%$ \\
\hline 8 & Invitation & Acceptance/refusal & 2 & $1.94 \%$ \\
\hline 9 & Assessment & Agreement/disagreement & 4 & $3.88 \%$ \\
\hline 10 & Command & Compliance/incompliance & 4 & $3.88 \%$ \\
\hline 11 & Suggestion & Acceptance/refusal & 4 & $3.88 \%$ \\
\hline 12 & Assertion & Agreement/disagreement & 5 & $4.85 \%$ \\
\hline 13 & Announcement & Acknowledge & 6 & $5.82 \%$ \\
\hline & & Total & 103 &
\end{tabular}

The following table (Table 3.3) provides the data of preference organization of adjacency pairs in drama script "Teen Angel". The second pair part has two options in responding the first pair that are preferred and dispreferred. 
Table 3.3 Preference Organization of Adjacency Pair

\begin{tabular}{|c|c|c|c|c|c|}
\hline \multirow[t]{2}{*}{ No } & \multirow[t]{2}{*}{ First Pair Part } & \multicolumn{2}{|c|}{ Second Pair Part } & \multirow[t]{2}{*}{ Amount } & \multirow[t]{2}{*}{ Percentage } \\
\hline & & Preferred & Dispreferred & & \\
\hline 1 & Question & 55 (Answer) & - & 55 & $66.26 \%$ \\
\hline 2 & Request & - & 1 & 1 & $1.20 \%$ \\
\hline 3 & Offer & 4 & 2 & 6 & $7.22 \%$ \\
\hline 4 & Blame & - & 2 & 2 & $2.40 \%$ \\
\hline 5 & Invitation & 2 & - & 2 & $2.40 \%$ \\
\hline 6 & Assessment & 4 & - & 4 & $4.81 \%$ \\
\hline 7 & Command & 3 & 1 & 4 & $4.81 \%$ \\
\hline 8 & Suggestion & 4 & - & 4 & $4.81 \%$ \\
\hline \multirow[t]{2}{*}{9} & Assertion & 5 & - & 5 & $6.02 \%$ \\
\hline & & TOTAL & & 83 & \\
\hline
\end{tabular}

\section{Pre-sequence and Insertion sequence}

\section{Pre-sequence}

Sometimes, when first and second pair part exchange turn, the first pair part begins with delivering pre-utterance. Pre-utterance uses before the base utterance expose. In this drama script, there are 5 data which has pre-sequence in the beginning of utterance, 3 data of question type, 1 data of invitation type and 1 data of assertion type. The following data is the example of pre-sequence in invitation type.

David : Then let's find you a boat. Oh, I love this song.

Peggy :Me too.

David :Want to dance?

Peggy :I'd love to.

The first pair part gave pre-utterance by saying "Oh, I love this song”. The second pair part gave response, in the form of pre-utterance, by uttering "Me too". Next, the first second pair came with the base utterance to invite the second pair part, "Want to dance?". The second pair part gave preferred answer by saying "I'd love too".

\section{Insertion sequence}

Compare to pre-sequence, insertion sequence is happened when there are utterances occurs in the middle of first pair part base utterance and second pair part base utterance. In this drama script, there are 2 data in which insertion sequence occurs.
Rick : Do you want to dance?
(FPP base)
Kate :Now? $(S P P$ i)
Rick : Sure. Why not?
(FPP i)
Kate : Okay.
(SPP base)

The first pair part give invitation to the second pair part by saying "Do you want to dance?" The second pair part did not give direct response toward that invitation, yet she asks a question "Now?" This question considers as insertion sequence. The first pair part, next, gave insertion sequence "Sure. Why not?" and the second pair part provided preference in the form of acceptance by saying "Okay". The result of analysis of pre-sequence and insertion sequence are provided in Table 3.4.

Table 3.4 Pre-sequence and Insertion sequence

\begin{tabular}{lll}
\hline No & Pre-sequence & Amount \\
\hline 1. & Question & 3 \\
\hline 2. & Invitation & 1 \\
\hline 3. & Assertion & 1 \\
\hline No & Insertion sequence & Amount \\
\hline 1. & Greeting & 1 \\
\hline 2. & Offer & 1 \\
\hline
\end{tabular}




\section{CONCLUSIONS}

Adjacency Pairs is one of the fundamental aspects in conversation as in the conversation there is a term called turn-taking. Dealing with adjacency pairs, there are some types of adjacency pairs which have different response. The response can be in the form of preferred or dispreferred form. Also, talking about conversation, there a term that called as pre-sequence and insertion sequence.

Based on the analysis that the researcher has done, there are 245 turns in the drama script "Teen Angel" by M.D Larson. Deeper analysis was conducted and there is found some data which are categorized as turn-taking. Furthermore, the researcher classified the 103 data of adjacency pair into 13 types of adjacency pairs. Besides the types of adjacency pair, the researcher also found some data which have presequence and intersection sequence. There are 5 pre-sequence and 2 insertion sequences.

\section{REFERENCES}

Coulthard, M. (1985). An Introduction to Discourse Analysis. Second Edition. Harlow: Longman.

Herritage, J. (2001). Conversation Analysis: Sociological. International Encyclopedia of the Social \& Behavioral Sciences

Levinson, S C. (1983). Pragmatics. Cambridge University Press

Paltridge, B. (2006). Discourse Analysis: An Introduction. New York: Continuum

Pomerantz, A. (1984). Agreeing and Disagreeing with Assessments: Some Features of Preferred/Dispreferred Turn Shapes. In J. M. Atkinson and J. Heritage (ed.) Structures of Social Action: Studies in Conversation Analysis. Cambridge: Cambridge University Press

Schegloff, Emanuel A. (2007).Sequence Organization in Interaction A Primer in Conversation Analysis (Volume 1). Cambridge: Cambridge University Press 